\title{
Study of the floristic, functional and phylogenetic composition of trees in a short time in a forest fragment of the Atlantic Forest, Brazil
}

\author{
Estudio de la composición florística, funcional y filogenética de árboles en poco tiempo \\ en un fragmento de bosque del bosque atlántico, Brasil
}

\author{
Gabriela Gomes Pires de Paula a*, Cleber Rodrigo de Souza a, Vinícius Andrade Maia a, \\ Natalia de Aguiar-Campos ${ }^{a}$, Nathalle Cristine Alencar Fagundes ${ }^{\text {b }}$, Fernanda Moreira Gianasi ${ }^{\text {b }}$, \\ Diego Teixeira Girardelli ${ }^{a}$, Aurélio de Jesus Rodrigues Pais ${ }^{a}$, Wilder Bento da Silva ${ }^{\text {a, }}$ \\ Rubens Manoel dos Santos a \\ *Corresponding author: ${ }^{a}$ Federal University of Lavras, Science Forest Department, 3037 Brazil, \\ gabyfloresta@gmail.com \\ ${ }^{\mathrm{b}}$ Federal University of Lavras, Botany Department, 3037 Brazil.
}

\begin{abstract}
SUMMARY
Discrete thresholds of structural or functional decline of a vegetation type are not readily apparent, as a vegetation type can slowly decline leading to transformations in its species composition and weakened or altered functions. However, forest monitoring can be used to assess changes in ecological functions in community structure and functional and phylogenetic composition of species. This study evaluated the existence of temporal variations in the functional and phylogenetic composition of a tree community, the occurrence of heterogeneity in the behavior of phylogenetic and functional variations, and how this possible heterogeneity influences the functional and phylogenetic variations under the aspect of environmental variations and by demographic ecological processes. Results detected quantitative and qualitative changes throughout the community, such as colonization, local extinctions, in demography and biomass, and increased evolutionary distinction, lower wood density species and phylogenetic clustering. These results have shown us that the natural changes of a community should not be underestimated, because the disappearance of a community can not only occur by the direct elimination of vegetation, but can be incremental with gradual changes in its functional characteristics and species composition, transforming itself into a new community with a new combination of species and new functions.
\end{abstract}

Key words: functional attributes, forest ecology, Atlantic forest, phylogeny, forest dynamics.

\section{RESUMEN}

Los umbrales discretos de deterioro estructural o funcional de un tipo de vegetación no son fácilmente aparentes, ya que un tipo de vegetación puede disminuir lentamente, lo que lleva a transformaciones en la composición de sus especies y funciones debilitadas o alteradas. Sin embargo, las observaciones pueden usarse para evaluar los cambios en las funciones ecológicas antes de que esto ocurra a través de la estructura comunitaria y la composición funcional y filogenética de las especies. Este estudio evaluó la existencia de variaciones temporales en la composición funcional y filogenética de una comunidad arbórea; la ocurrencia de heterogeneidad en el comportamiento de variaciones filogenéticas y funcionales; y cómo esta posible heterogeneidad influye en las variaciones funcionales y filogenéticas bajo el aspecto de variaciones ambientales y por procesos demográficos ecológicos. Los resultados en la detección de cambios cuantitativos y cualitativos en toda la comunidad con la colonización y las extinciones locales en la comunidad, las diferencias demográficas y de biomasa, la distinción evolutiva aumentada, las especies de menor densidad de madera y el agrupamiento filogenético. Los resultados han demostrado que los cambios naturales de una comunidad no deben subestimarse, porque la desaparición de una comunidad no solo puede ocurrir por la eliminación directa de la vegetación, sino que puede ser incremental con cambios graduales en sus características funcionales y composición de especies, transformando en una nueva comunidad con una nueva combinación de especies y nuevas funciones.

Palabras clave: atributos funcionales, ecología forestal, bosque atlántico, filogenia, dinámica forestal.

\section{INTRODUCTION}

Knowledge about the worldwide conservation status of biodiversity, as well as its human use, has faced a growing demand worldwide, which has been driving increasing support for strategies of natural resource management, nature protection and sustainable resource use. The perception and quantification of biodiversity change over time 
are nonetheless a great challenge, especially when gradual, low-intensity changes are observed within short timespans in a local or regional geographic range. The lack of temporal studies on this matter prevents the assessment of the actual status of biodiversity (Del Vecchio et al. 2016).

Changes in biodiversity may encompass more than species richness decline, but entails alterations in the identity of species and, potentially, in community function (Hillebrand et al. 2018). From the human perspective, these shifts can hamper the provision of ecosystem services such as food sources, fuel, structural materials, medicines and genetic resources (Chapin et al. 2000). The abundances of species that control ecosystem processes may also be compromised, leading to further compositional changes in the community and, consequently, increasing vulnerability to species invasion (Navarro et al. 2017). Although the reduction in species distribution may be detected with relative ease, discrete thresholds of structural or functional decline are not easily perceptible (Del Vecchio et al. 2016).

According to a recent study, since the year 1900, seed plants have been extinguishing by a rate of approximately three species per year, with emphasis on island and wet tropics floras (Humphreys et al. 2019). In Brazil, the greatest loss has occurred in the south-eastern region where the Atlantic Forest vegetation predominates, with 21 to 30 species becoming extinct within the last 119 years (Humphreys et al. 2019). For its high biological relevance and anthropogenic threats faced by its highly endemic flora, the Atlantic Forest is considered a hotspot of biodiversity (Ribeiro et al. 2009). The broad range of agricultural land uses and lack of an efficient forest management plan threaten the Atlantic Forest remnants (Becker et al. 2013), specifically in Mantiqueira Range (Serra da Mantiqueira), inserted in a densely populated area that neighbors large cities like Rio de Janeiro and São Paulo. One of the main issues concerning Atlantic Forest conservation is the intense fragmentation process that it has undergone since the beginning of colonization in the sixteenth century, which resulted in its occurrence being currently restricted to small scattered fragments (Ribeiro et al. 2009).

Wet tropical regions are characterized by high annual rainfall and high evapotranspiration rates, with drought being an important driver of diversity patterns and survival of species in tropical forests (Esquivel-Muelbert et al. 2017). However, with the likely changes in precipitation regimes promoted by climate change, many plant species may not be able to adapt fast enough nor to track suitable habitats in terms of water availability (Esquivel-Muelbert et al. 2017). Moreover, in a given ecosystem, niche opportunities that stem from climatic fluctuations over time can determine which species will be able to occupy these novel niche dimensions and which functions may be provided or lost (Pulla et al. 2017, Maia et al. 2020). Such niche opportunities can explain changes in species composition and forest productivity, as well as species colonization and occupation strategies (Pulla et al. 2017).
In view of all this context, it is important to note that in 2010, the Parties to the Convention on Biological Diversity adopted the Strategic Plan for Biodiversity 2011-2020 and its 20 associated Aichi Biodiversity Targets. Aichi Biodiversity Target 19 refers specifically to knowledge, values, functioning, situations and trends about biodiversity through its monitoring. Although long term studies are important for monitoring the conservation status of biodiversity in vegetation fragments, detecting changes in shorter periods offers interesting possibilities to observe more specific changes in the taxonomy, phylogeny, structure and functions of the community, as well as interactions between them. Importantly, these short-term assessments of biodiversity change may serve as an alert before detrimental and irreversible alterations occur.

We, field researchers, were able to see in the surveys that even in a short period of time, forest communities have been reflecting perceptible changes in their physiognomy. And for that, we tested the following hypothesis: Over a period of six years, are the changes that occur in the community due to the effect of demographic fluctuations able to reflect on ecological functions and alter the phylogeny of a community? To explore this hypothesis, this study seeks to relate: (i) if taxonomic composition changed between the intervals (controlling soil effects) and (ii) if taxonomic composition, along with community dynamics, phylogenetic diversity shifts and soil, leads to shifts in community structure, community function, above-ground woody biomass and evolutionary distinctiveness.

\section{METHODS}

Study area. This study was carried out in an area inserted in the Atlantic domain, in Mantiqueira Range (Serra da Mantiqueira, in Portuguese), south-east Brazil. The studied forest fragment is named Mata dos Gnomos (Gnome Woods, in free translation) and is located in a private natural heritage reserve (RPPN Altomontana) in the Municipality of Itamonte, Minas Gerais State (figure 1). Mata dos Gnomos is a semideciduous forest disjunction inserted in a matrix of ombrophilous forests (OliveiraFilho 2009), and its altitude ranges from 1,445 to $1,495 \mathrm{~m}$.

The climate of the region is Cwb according to the Koppen classification, mesothermic with dry winters (June-July) and rainy with mild summers (December-January). The temperature varies from $17.4{ }^{\circ} \mathrm{C}$ to $19.8^{\circ} \mathrm{C}$, not exceeding 22 ${ }^{\circ} \mathrm{C}$, and average annual rainfall is $1,749 \mathrm{~mm}$. The fragment has been under protection as a private natural heritage reserve for about 80 years, with presence of some remaining old trails inside the forest, which has presence of the Brazilian pine Araucaria angutistifolia (Bertol.)_Kuntze. Adjacent to this fragment, there are ecotonal areas: one of them with monodominance of bamboo and another with dominance of candeia (Eremanthus erythropappus (DC.) MacLeish).

To better analyze the behavior of precipitation, and thus be able to infer about changes in precipitation over time, 
we took the precipitation data in the interval from 2005 to 2017. This analysis was made only to set up a scenario of rainfall distribution over time, to help in understanding the behavior of the forest under study. The study area had a rainfall coefficient of variation of $21.27 \%$ and its annual rainfall profile is displayed in figure 2.

Data collection. In 2011, 22 plots of $400 \mathrm{~m}^{2}$ were established along five transects, spaced $10 \mathrm{~m}$ apart. All arboreal individuals with diameter at breast height $(\mathrm{DBH}) \geq 5 \mathrm{~cm}$ within these plots were measured. For trees with multiple stems, we included those of which the square-root of the sum of squares of each stem DBH met the inclusion criterion (DBH $\geq 5 \mathrm{~cm}$ ). The plots were resurveyed in 2017 and all surviving trees were re-measured. New individuals that reached the inclusion criterion (recruits, $\mathrm{DBH} \geq 5 \mathrm{~cm}$ ) were identified to the species level, measured in terms of DBH and height and marked with numbered aluminum tags, while dead individuals were also recorded.

In each plot, one soil sample was collected at a depth of 0 to $10 \mathrm{~cm}$ to characterize soil physical and chemical aspects. The following attributes were assessed: aluminum,
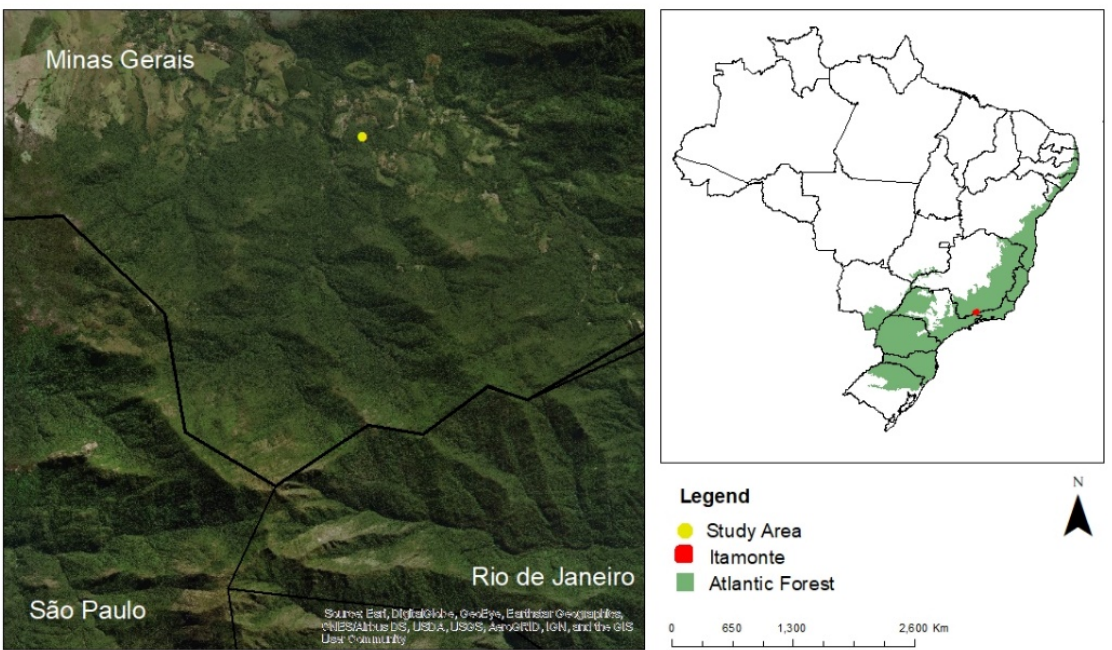

Figure 1. Study area location (Itamonte) in Minas Gerais State, Brazil, and Brazilian biogeographic domain of area.

Ubicación del área de estudio (Itamonte) en el estado de Minas Gerais, Brasil, y el dominio biogeográfico brasileño del área.

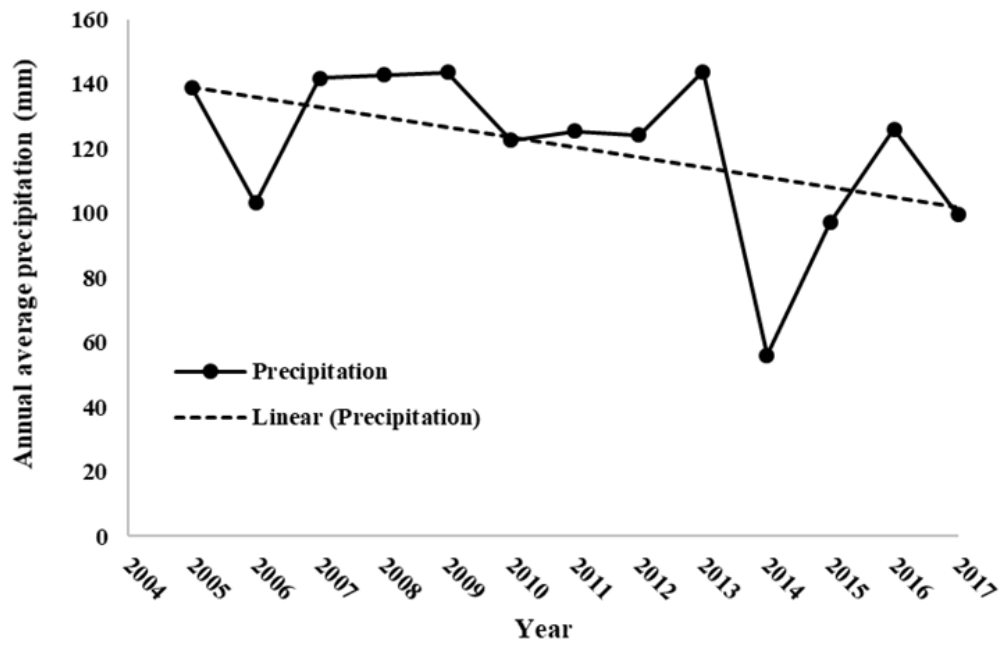

Figure 2. Total annual precipitation from 2004 to 2017 in the study region of Itamonte, Minas Gerais State, Brazil. Data obtained from Instituto Nacional de Meteorologia (INMET)-BDMEP database, collected from the meteorological station of São Lourenço Municipality.

Precipitación total anual de 2004 a 2017 en la región de estudio de Itamonte, estado de Minas Gerais, Brasil. Datos obtenidos de la base de datos del Instituto Nacional de Meteorología (INMET) -BDMEP, recopilados de la estación meteorológica del municipio de São Lourenço. 
sum of bases, organic matter, $\mathrm{pH}$ in water and sand, silt and clay proportions $(\mathrm{dag} / \mathrm{kg})$ to characterize soil texture.

Tree identification followed APG IV and was performed in the field, or else by consulting experts or the ESAL Herbarium at the Federal University of Lavras (UFLA). Species nomenclature followed The Plant List database (theplantlist.org) in case synonyms were eventually recorded.

From the species abundance matrix and using the vegan package (Oksanen et al. 2018), we performed a Detrended Correspondence Analysis (DCA) using data from both inventories to synthesize differences in taxonomic composition among plots (i.e. beta diversity).

Biomass and productivity were calculated following the methodology described by Poorter et al. (2017), assuming that biomass stocks and dynamics are key ecosystem functions because biomass largely mediates local and global biogeochemical cycles in carbon, nutrients and water (Chapin et al. 2000). Productivity was obtained by the difference in the biomass between the inventories (biomass of the last year minus the biomass of the first year).

Obtaining variables of interest. Variables, aimed at describing the functional composition of each sample unit at each data collection year, were obtained through the community weighted means (CWMs) of the following attributes: wood density (WD), obtained from the Global Wood Density Database through values for species or averages of the genus or family (Chave et al. 2009); sprouting intensity (Spr intensity - \%), obtained by the ratio between the number of stems and the number of individuals; sprouting frequency (number of individuals that have more than one stem/ number of individuals - Spr frequency - \%); and species' maximum DBH $(\mathrm{cm})$. The CWM values were calculated with the $\mathrm{R}$ function functcomp from the FD package $\mathrm{v}$. 3.5.2 (2018) (Laliberté et al. 2014). The Evolutionary Distinctiveness (ED) metric was obtained for each species by dividing the total phylogenetic diversity of a clade among its members, applying a value to each branch equal to its length divided by the number of species belonging to the branch; species with no close relatives have high ED values, and a community with high ED values is considered to have more evolutionarily unique species (Edwards et al. 2017). We also calculated the CWM of this metric to obtain a single value of evolutionary distinctiveness for each sample unit. For each measurement year, we calculated the standardized effect sizes (SES) of phylogenetic diversity (PD), mean pairwise distance (MPD) and mean nearest taxon distance (MNTD), aiming at neutralizing the bias caused by variations in species richness across sample units. We used the packages V.PhyloMaker (Jin and Qian 2019), PhyloMeasures (Tsirogiannis and Sandel 2016) and the mega angiosperm tree GBOTB.extended to build our tree and obtain the metrics of ED diversity and phylogenetics.

Based on the abundances of dead individuals and recruits, we calculated the annual mortality and recruitment rates as proposed by Sheil et al. (1995). The above-ground woody biomass (AGWB, in $\mathrm{Mg}$ ) of dead individuals (AGWBdead) and of recruits (AGWBrec) was also calculated to evaluate the demographic fluctuations by changes in biomass and not only through changes in species abundances (Sheil et al. 1995). Biomass was obtained through the BIOMASS package (Rejou-Mechain et al. 2017), using the modified equation of Chave $\mathrm{et} \mathrm{al}$. (2014). We used equation with parameters for $\mathrm{DBH}$, wood density and $\mathrm{E}$, which is related to climate stress and predicts tree height when it is absent in the data. This equation has been developed and has been widely applied in rain forests, although with uncertain expectations when applied to other vegetation types. We calculated the temporal beta diversity for each sample unit using the squared distances between the coordinates of the plots in DCA axis 1 in the first census and in the second census. Only the DCA axis 1 was used in the analysis due to its eigenvalue of 0.45 against 0.22 from axis 2 . The soil variables were synthesized in two explanatory summary variables represented by the value of each sample unit on the two first axes of a Principal Component Analysis (PCA) performed with all the collected soil variables (figure $\mathrm{S} 1$ ).

Data analyses. All analyses were performed in the environment $\mathrm{R}$ version 3.6.1 ( $\mathrm{R}$ Core Team 2019), adopting the significance level of $5 \%$ for all analyses.

Two matrices were used to test the change in species composition and functional attributes over time, each containing data from one of the inventories. We performed non-metric multidimensional scaling (nMDS) for the difference in species composition among sample units using Bray-Curtis dissimilarity. We used the Procrustes and ProTest analyses in both cases. The most commonly used method for Procrustean fit is based on the least squares criterion that minimizes the sum of square residuals (m) between the two configurations. The analyses were implemented using the vegan package.

Three main analyses were conducted with all the variables of interest regarding taxonomic composition, functional composition and phylogenetic diversity (DCA axis 1, CWM WD, AGWB, CWM sprouting frequency, CWM sprouting intensity, CWM maximum DBH and CWM evolutionary distinctiveness), as well as demographic variables (mortality and recruitment rates); AGWB of mortality, recruitment and productivity, environmental variables (edaphic PCA axes 1 and 2), and phylogenetic diversity variables (sesPD, sesMPD and sesMNTD). First, we tested if the taxonomic composition (Procrustes and DCA axis 1), functional composition (CWMs) and phylogenetic diversity metrics differ between the censuses and if its relationship with soil and taxonomic composition (except for DCA axis 1) shifted across the censuses. For this, we used Generalized Linear Mixed Effects Models (LMM). Plot was used as random factor because of the repeated measures at the same plot.

We, afterwards, evaluated if there are differences between the inventories in the mortality and recruitment rates and in the AGWB of recruitment and mortality through 
LMM. Finally, we also assessed potential relationships between the temporal variation of functional composition, community structure/dynamics and phylogenetic diversity with demographic, phylogenetic diversity variation, taxonomic composition shifts and edaphic variables. To do so, we obtained the percentage variation of the CWM of each attribute ([(CWM year 2 - CWM year 1$) / C W M$ year 1$]$ * 100) and for productivity (AGWB year 2 minus AGWB year 2) as a function of demographic variables (mortality, recruitment, AGWB of dead and AGWB of recruits), species substitution (DCA axis 1 squared distances), edaphic (PC1 and PC2) and variation in phylogenetic diversity ( $\Delta$ ses PD, $\Delta$ ses MPD and $\Delta$ ses MNTD, between years). In this case we used linear models (LM).

In the modelling approach we built a global model containing all the variables and dredged it to obtain models with all combinations of a maximum of two variables (due to the reduced number of observations) and which correlate by less than $|0.6|$. The models obtained with $\triangle \mathrm{AICc}$ less than or equal to 2 in relation to the best model were submitted to a multi-model inference, using the "model. avg" function of "MuMIn" package (Bartón 2009) to capture the uncertainty of the effects of all predictors on the response variables, so that the coefficients were averaged and significant values were obtained. All variables were worked within the Gaussian distribution family, assuming the criteria of residual normality (Shapiro-Wilk test) and absence of spatial autocorrelation in the global model by the ncf package correlog function (Bjørnstad 2008).

The variables, together with the analyses used and their functions, are found in a summary table1.

\section{RESULTS}

Overall, a total of 139 species were recorded: 135 species in the first inventory year (2011) and 131 in the second year (2017). In the first measurement, 1304 individuals with a total AGWB of $282.3 \mathrm{Mg}$ (density of 1552 individuals/ha; AGWB of $336.07 \mathrm{Mg} / \mathrm{ha}$ ) were recorded, whereas in the second measurement, 1189 individuals summing up $281.1 \mathrm{Mg}$ of AGWB (density of 1415 individuals/ha AGWB of 334.64 $\mathrm{Mg} / \mathrm{ha}$ ) were recorded. Mortality was significantly higher than recruitment through the six-year time span (figure 3).

Qualitative differences were identified in terms of the balance between recruitment and mortality for a few species between inventory years $-e$.g. mortality but no recruitment of Tachigali rugosa (Mart. ex Benth.) Zarucchi et Pipoly and Solanum leucodendron Sendtn. There were species that disappeared from the community and species that arrived in the community (e.g. Cyathea delgadii Ster$\mathrm{nb}$ ). Other species, like Leandra melastomoides Raddi, entered the community (table 2). The Procrustes for the nMDS

Table 1. Summary table with the variables used and their respective analyses and classification regarding the topic addressed.

Resumen de las variables utilizadas y sus respectivos análisis y clasificación con respecto al tema abordado.

\begin{tabular}{|c|c|c|c|c|}
\hline & Variables & Abbreviation & Analyses & Classification \\
\hline \multicolumn{3}{|c|}{ Species composition } & $\begin{array}{l}\text { nMDS; Procrustes } \\
\text { and ProTest; DCA }\end{array}$ & $\begin{array}{l}\text { Taxonomic } \\
\text { and functional }\end{array}$ \\
\hline \multicolumn{3}{|l|}{ Soil texture } & PC2 & Taxonomic \\
\hline \multicolumn{2}{|c|}{ Evolutionary distinctiveness } & ED & LMM & Phylogenetic \\
\hline \multirow{5}{*}{$\begin{array}{l}\text { Community } \\
\text { weighted means }\end{array}$} & Wood density & CWM WD & CWM WD & \multirow{5}{*}{ Functional } \\
\hline & Sprouting intensity & CWM Sprouting & CWM Sprouting & \\
\hline & Sprouting frequency & CWM Spr Freq & CWM Spr Freq & \\
\hline & Maximum DBH & CWM Max DBH & CWM Max DBH & \\
\hline & Evolutionary distinctiveness & CWM ED & CWM ED & \\
\hline \multicolumn{2}{|c|}{ Standardized phylogenetic diversity } & sesPD & LMM & Phylogenetic \\
\hline \multicolumn{2}{|c|}{ Standardized mean distance of pairs } & sesMPD & LMM & Phylogenetic \\
\hline \multicolumn{2}{|c|}{ Standardized average distance from the nearest taxon } & sesMNTD & LMM & Phylogenetic \\
\hline \multirow{5}{*}{ Demographic } & Mortality rate & & LMM & \multirow{5}{*}{$\begin{array}{l}\text { Taxonomic and } \\
\text { functional }\end{array}$} \\
\hline & Recruitment rate & & LMM & \\
\hline & Above-ground woody biomass & AGWB & LMM & \\
\hline & $\begin{array}{l}\text { Above-ground woody biomass of } \\
\text { dead individuals }\end{array}$ & AGWBdead & LMM & \\
\hline & $\begin{array}{l}\text { Above-ground woody biomass of } \\
\text { recruits }\end{array}$ & AGWBrec & LMM & \\
\hline
\end{tabular}




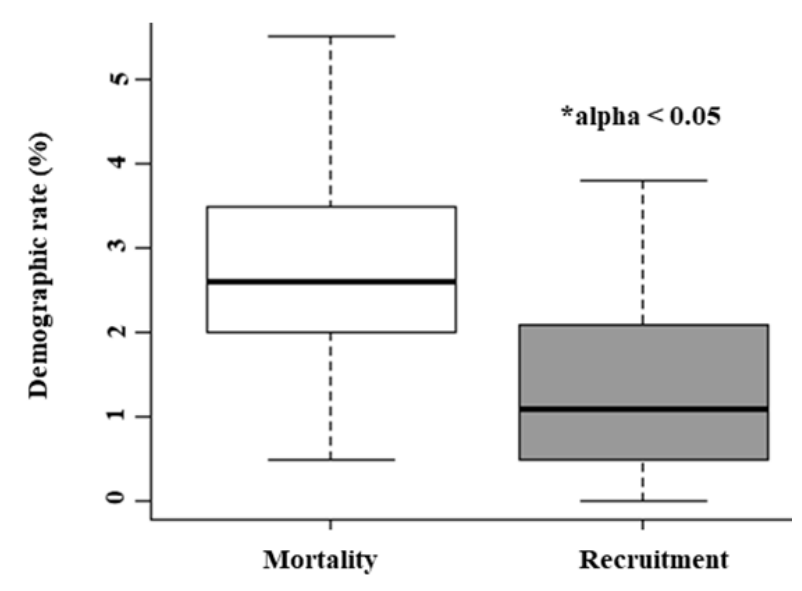

Figure 3. Mortality (\%) and recruitment (\%) of individuals observed between inventories for the sample units of the upper montane semi-deciduous tropical forest.

Mortalidad (\%) y reclutamiento (\%) de individuos observados entre inventarios para las unidades de muestra del bosque tropical montano superior. and CWM values corroborated these floristic differences (figure 4). The graphical description of the Procrustes and ProtTest analyses (figure 4) indicated that there occurred changes in species composition (Procrustes $\mathrm{m}^{2}=0.3618$; ProTest $0.7989, P<0.0001$ ) and functional traits (Procrustes $\mathrm{m}^{2}=0.3189$; ProTest $\left.0.8253, P<0.0001\right)$ of the sample units in the six-year period covered. The DCA axis 1 scores showed significant differences between the communities sampled in 2011 and $2017(P=0.01)$, indicating that the taxonomic composition changed in the interval. Both variables related to sprouting differed significantly between censuses (2011 and 2017) and were strongly affected by species composition (DCA axis 1$)(P<0.001$ for both). The CWM of maximum diameter showed a significant relationship with soil (PC2) $(P<0.001)$, with decrease in soil effect over this response variable between inventory years (figure 5A). The CWM of evolutionary distinctiveness only displayed significant relationships with the interaction between species composition (DCA axis 1) and year 2, in a way that the effect of species composition on evolutionary distinctiveness CWM increased in the second inventory (figure $5 \mathrm{~B}$ ). This indicates that the evolutionary
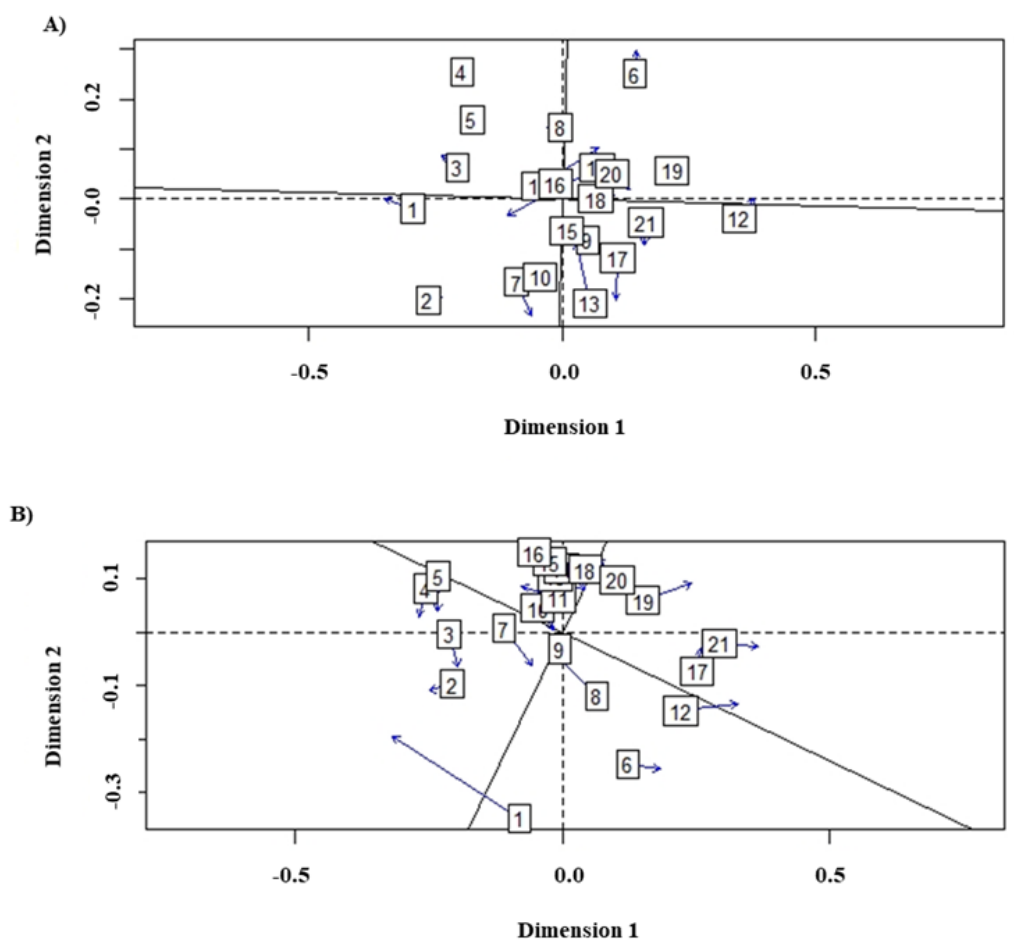

Figure 4. Procrustes Graph generated from (A) nMDS results and (B) CWM values. The numbers represent the sample units. The distance between the two inventories is the residual of Procustes. Longer arrows indicate residuals with higher values (i.e. a larger difference in species composition/CWM between a pair of samples). The numbers are equivalent to the plots, the arrows indicate the direction and size of the change.

Gráfico de Procrustes generado a partir de (A) resultados de nMDS y (B) valores de CWM. Los números representan las unidades de muestra. La distancia entre los dos inventarios es el residuo de Procustes. Las flechas más largas indican residuos con valores más altos (es decir, una diferencia mayor en la composición de especies/CWM entre un par de muestras). Los números son equivalentes a los gráficos, las flechas indican la dirección y el tamaño del cambio. 


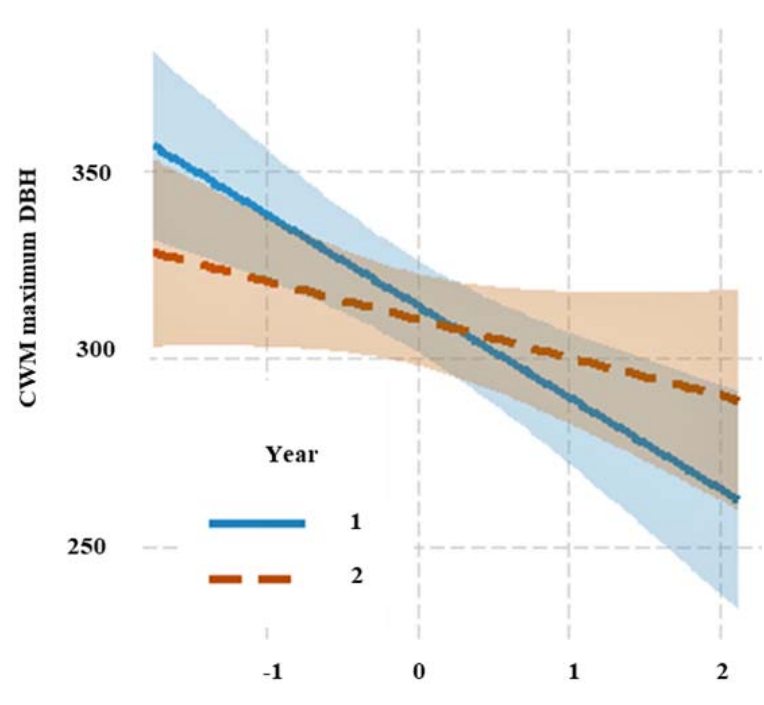

PCA axis 2

Figure 5. Relationships of temporal shift community-weighted mean (CWM) of: (A) maximum diameter (DBH maximum) with the soil (PC2), (B) evolutionary distinctiveness (ED) with species composition (DCA). The shades are the confidence bands of the fitted lines.

Relaciones del cambio temporal media ponderada por la comunidad (CWM) de: (A) diámetro máximo (DBH máximo) con el suelo (PC2); (B) distinción evolutiva (ED) con la composición de especies (DCA). Las sombras son las bandas de confianza de las líneas ajustadas.

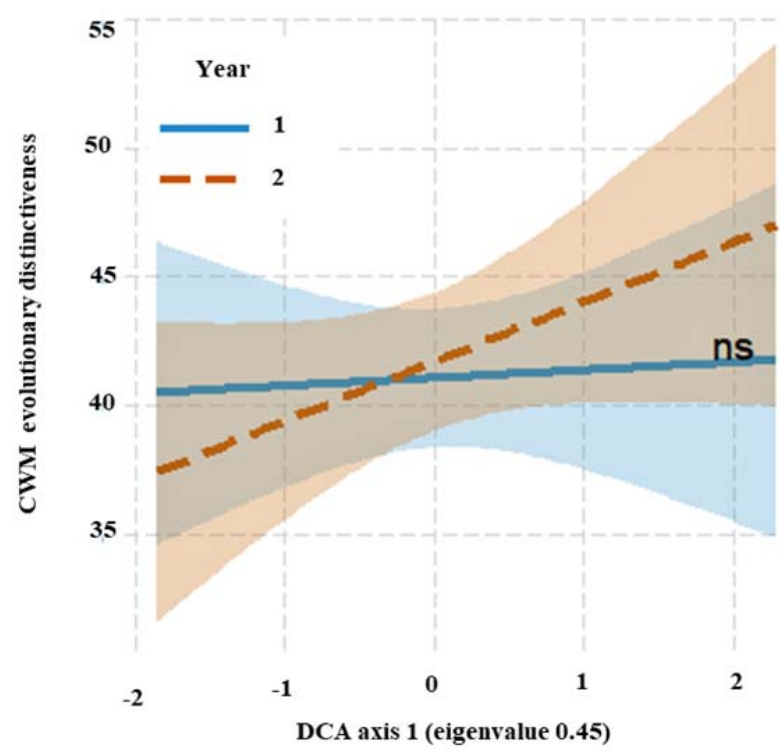

Figure 6. Relationships of temporal shift community- weighted mean (CWM) of evolutionary distinctiveness (ED) with species composition (DCA). The shades are the confidence bands of the fitted lines.

Relaciones de cambio temporal ponderadas por la comunidad media (CWM) de distinción evolutiva (ED) con composición de especies (DCA). Las sombras son las bandas de confianza de las lìneas ajustadas.

Table 2. Table with the floristic balance of the 6-year interval with its respective evolutionary distinction value. Code: 0 dead and no recruits. NA-These species did not have their ED calculated due to the name being under review.

Balance florístico del intervalo de seis años con su respectivo valor de distinción evolutiva. Código: $O$ muertos y sin reclutas. NA: estas especies no tenían su ED calculado debido al nombre que se estaba revisando.

\begin{tabular}{|c|c|c|c|c|}
\hline Species & Family & ED & 2011 & 2017 \\
\hline Alchornea glandulosa Poepp. et Endl. $\bigcirc$ & Euphorbiaceae & 47.51 & $\mathrm{X}$ & $\mathrm{X}$ \\
\hline Alchornea triplinervia (Spreng.) Müll.Arg. & Euphorbiaceae & 47.51 & $\mathrm{X}$ & $\mathrm{X}$ \\
\hline Allophylus puberulus (Cambess.) Radlk. & Sapindaceae & 55.49 & $\mathrm{X}$ & $\mathrm{X}$ \\
\hline Amaioua intermedia Mart. ex Schult. et Schult.f. & Rubiaceae & 59.78 & $\mathrm{X}$ & $\mathrm{X}$ \\
\hline Annona cacans Warm. $\bigcirc$ & Annonaceae & 43.40 & $\mathrm{X}$ & $\mathrm{X}$ \\
\hline Annona emarginata (Schltdl.) H. Rainer & Annonaceae & 43.40 & $\mathrm{X}$ & $\mathrm{X}$ \\
\hline Araucaria angustifolia (Bertol.) Kuntze $\bigcirc$ & Araucariaceae & 325.5 & $\mathrm{X}$ & $\mathrm{X}$ \\
\hline Aspidosperma australe Müll.Arg. & Apocynaceae & 43.99 & $\mathrm{X}$ & $\mathrm{X}$ \\
\hline Aspidosperma olivaceum Müll.Arg. $\bigcirc$ & Apocynaceae & 43.99 & $\mathrm{X}$ & $\mathrm{X}$ \\
\hline Blepharocalyx salicifolius (Kunth) O. Berg & Myrtaceae & 33.94 & $\mathrm{X}$ & $\mathrm{X}$ \\
\hline Byrsonima laxiflora Griseb. & Malpighiaceae & NA & $\mathrm{X}$ & $\mathrm{X}$ \\
\hline Cabralea canjerana (Vell.) Mart. $\bigcirc$ & Meliaceae & 52.82 & $\mathrm{X}$ & $\mathrm{X}$ \\
\hline Calyptranthes grandiflora $\mathrm{O}$. Berg & Myrtaceae & 28.42 & $\mathrm{X}$ & $\mathrm{X}$ \\
\hline Calyptranthes widgreniana $\mathrm{O}$. Berg $\bigcirc$ & Myrtaceae & 28.42 & $\mathrm{X}$ & $\mathrm{X}$ \\
\hline Campomanesia guaviroba (DC.) Kiaersk. & Myrtaceae & 27.79 & $\mathrm{X}$ & $\mathrm{X}$ \\
\hline
\end{tabular}


Table 2 Continued

\begin{tabular}{|c|c|c|c|c|}
\hline Campomanesia guazumifolia (Cambess.) O. Berg & Myrtaceae & 27.79 & $\mathrm{X}$ & $\mathrm{X}$ \\
\hline Campomanesia xanthocarpa (Mart.) O. Berg & Myrtaceae & 27.79 & $\mathrm{X}$ & $\mathrm{X}$ \\
\hline Casearia decandra Jacq. & Salicaceae & 44.79 & $X$ & $\mathrm{X}$ \\
\hline Casearia mariquitensis Kunth & Salicaceae & 44.79 & $\mathrm{X}$ & $\mathrm{X}$ \\
\hline Casearia sylvestris Sw. & Salicaceae & 44.79 & $\mathrm{X}$ & $\mathrm{X}$ \\
\hline Cinnamomum glaziovii (Mez) Kosterm. & Lauraceae & 19.69 & $\mathrm{X}$ & $\mathrm{X}$ \\
\hline Clethra scabra Pers. & Clethraceae & 98.01 & $\mathrm{X}$ & $\mathrm{X}$ \\
\hline Cyathea delgadii Sternb. & Cyatheaceae & 390.70 & $X$ & \\
\hline Cybianthus peruvianus (A.DC.) Miq. & Primulaceae & 40.61 & $X$ & $\mathrm{X}$ \\
\hline Cybistax antisyphilitica (Mart.) Mart. & Bignoniaceae & 37.18 & $\mathrm{X}$ & $\mathrm{X}$ \\
\hline Dalbergia frutescens (Vell.) Britton & Fabaceae & 73.57 & $X$ & $\mathrm{X}$ \\
\hline Daphnopsis coriacea Taub. & Thymelaeaceae & 60.35 & $\mathrm{X}$ & \\
\hline Daphnopsis utilis Warm. & Thymelaeaceae & 60.35 & $\mathrm{X}$ & $\mathrm{X}$ \\
\hline Dendropanax cuneatus (DC.) Decne. et Planch. & Araliaceae & 57.42 & $X$ & $\mathrm{X}$ \\
\hline Dictyoloma vandellianum A.Juss. & Rutaceae & 74.24 & $\mathrm{X}$ & $\mathrm{X}$ \\
\hline Diplotropis ferruginea Benth. & Fabaceae & 65.50 & $\mathrm{X}$ & $\mathrm{X}$ \\
\hline Eremanthus erythropappus (DC.) MacLeish 0 & Asteraceae & 30.92 & $X$ & $\mathrm{X}$ \\
\hline Eugenia hiemalis Cambess. & Myrtaceae & 31.67 & $\mathrm{X}$ & $\mathrm{X}$ \\
\hline Eugenia sonderiana $\mathrm{O}$. Berg & Myrtaceae & 31.67 & $X$ & $\mathrm{X}$ \\
\hline Euplassa legalis (Vell.) I.M.Johnst. & Proteaceae & 50.91 & $\mathrm{X}$ & \\
\hline Euplassa rufa (Loes.) Sleumer & Proteaceae & 50.91 & $X$ & $\mathrm{X}$ \\
\hline Ficus enormis Mart. ex Miq. & Moraceae & 77.84 & $X$ & $\mathrm{X}$ \\
\hline Laplacea fruticosa (Schrad.) Kobuski & Theaceae & 98.45 & $\mathrm{X}$ & $\mathrm{X}$ \\
\hline Guapira opposita (Vell.) Reitz & Nyctaginaceae & 122.00 & $X$ & $\mathrm{X}$ \\
\hline Guatteria australis A.St.-Hil. & Annonaceae & 42.99 & $X$ & $\mathrm{X}$ \\
\hline Guatteria villosissima A.St.-Hil. & Annonaceae & 42.99 & $\mathrm{X}$ & $\mathrm{X}$ \\
\hline Handroanthus chrysotrichus (Mart. ex DC.) Mattos & Bignoniaceae & 37.18 & $\mathrm{X}$ & $\mathrm{X}$ \\
\hline Ilex brevicuspis Reissek & Aquifoliaceae & 105.70 & $X$ & \\
\hline Jacaranda macrantha Cham. & Bignoniaceae & 27.68 & $\mathrm{X}$ & $\mathrm{X}$ \\
\hline Jacaranda puberula Cham. & Bignoniaceae & 27.68 & $\mathrm{X}$ & $\mathrm{X}$ \\
\hline Jacaranda subalpina Morawetz & Bignoniaceae & 27.68 & $\mathrm{X}$ & $\mathrm{X}$ \\
\hline Lamanonia ternata Vell. & Cunoniaceae & 100.40 & $\mathrm{X}$ & $\mathrm{X}$ \\
\hline Leandra aurea (Cham.) Cogn. & Melastomataceae & 15.81 & $X$ & $\mathrm{X}$ \\
\hline Leandra melastomoides Raddi & Melastomataceae & 16.44 & & $\mathrm{X}$ \\
\hline Leandra quinquedentata (DC.) Cogn. & Melastomataceae & 15.81 & $\mathrm{X}$ & $\mathrm{X}$ \\
\hline Leucochloron incuriale (Vell.) Barneby et J.W.Grimes & Fabaceae & 65.65 & $\mathrm{X}$ & $\mathrm{X}$ \\
\hline Matayba guianensis Aubl. & Sapindaceae & 55.47 & $\mathrm{X}$ & $\mathrm{X}$ \\
\hline Maytenus gonoclada Mart. & Celastraceae & 45.28 & $\mathrm{X}$ & $\mathrm{X}$ \\
\hline Maytenus ilicifolia Mart. ex Reissek & Celastraceae & 37.89 & $\mathrm{X}$ & $\mathrm{X}$ \\
\hline Maytenus robustoides Loes. & Celastraceae & 45.28 & $\mathrm{X}$ & $\mathrm{X}$ \\
\hline Maytenus salicifolia Reissek & Celastraceae & 37.89 & & $\mathrm{X}$ \\
\hline
\end{tabular}


Table 2 Continued

\begin{tabular}{|c|c|c|c|c|}
\hline Miconia cabussu Hoehne & Melastomataceae & 17.89 & $\mathrm{X}$ & $\mathrm{X}$ \\
\hline Miconia chartacea Triana $\bigcirc$ & Melastomataceae & 13.69 & $\mathrm{X}$ & $\mathrm{X}$ \\
\hline Miconia cinnamomifolia (DC.) Naudin $\bigcirc$ & Melastomataceae & 15.60 & $\mathrm{X}$ & $\mathrm{X}$ \\
\hline Miconia corallina Spring & Melastomataceae & 13.69 & $\mathrm{X}$ & \\
\hline Miconia latecrenata (DC.) Naudin & Melastomataceae & 15.60 & $\mathrm{X}$ & $X$ \\
\hline Miconia pusilliflora (DC.) Naudin & Melastomataceae & 15.56 & & $\mathrm{X}$ \\
\hline Miconia sellowiana Naudin $\bigcirc$ & Melastomataceae & 15.56 & $\mathrm{X}$ & $\mathrm{X}$ \\
\hline Miconia willdenowii Klotzsch ex Naudin & Melastomataceae & 13.82 & $\mathrm{X}$ & $\mathrm{X}$ \\
\hline Mollinedia argyrogyna Perkins & Monimiaceae & 108.70 & $\mathrm{X}$ & $\mathrm{X}$ \\
\hline Myrcia fenzliana O.Berg & Myrtaceae & 27.85 & $\mathrm{X}$ & $\mathrm{X}$ \\
\hline Myrcia guianensis (Aubl.) DC. $\bigcirc$ & Myrtaceae & 27.43 & $\mathrm{X}$ & $\mathrm{X}$ \\
\hline Myrcia multiflora (Lam.) DC. & Myrtaceae & 27.10 & $\mathrm{X}$ & $\mathrm{X}$ \\
\hline Myrcia obovata (O.Berg) Nied. & Myrtaceae & 27.85 & $\mathrm{X}$ & $\mathrm{X}$ \\
\hline Myrcia pulchra (O.Berg) Kiaersk. & Myrtaceae & 27.12 & $\mathrm{X}$ & $\mathrm{X}$ \\
\hline Myrcia splendens (Sw.) DC. & Myrtaceae & 27.10 & $\mathrm{X}$ & $\mathrm{X}$ \\
\hline Myrcia venulosa DC. & Myrtaceae & 27.85 & $\mathrm{X}$ & $\mathrm{X}$ \\
\hline Myrciaria floribunda (H.West ex Willd.) O.Berg & Myrtaceae & 32.10 & $\mathrm{X}$ & \\
\hline Myrsine lineata (Mez) Imkhan. & Primulaceae & 39.90 & $\mathrm{X}$ & $\mathrm{X}$ \\
\hline Myrsine umbellata Mart. & Primulaceae & 39.90 & $\mathrm{X}$ & $\mathrm{X}$ \\
\hline Nectandra grandiflora Nees & Lauraceae & 14.31 & $\mathrm{X}$ & $\mathrm{X}$ \\
\hline Nectandra nitidula Nees & Lauraceae & 14.31 & $\mathrm{X}$ & \\
\hline Nectandra oppositifolia Nees & Lauraceae & 14.40 & $\mathrm{X}$ & $\mathrm{X}$ \\
\hline Ocotea aciphylla (Nees et Mart.) Mez $\bigcirc$ & Lauraceae & 16.39 & $\mathrm{X}$ & $\mathrm{X}$ \\
\hline Ocotea corymbosa (Meisn.) Mez & Lauraceae & 15.88 & $\mathrm{X}$ & $\mathrm{X}$ \\
\hline Ocotea diospyrifolia (Meisn.) Mez & Lauraceae & 16.36 & $\mathrm{X}$ & $\mathrm{X}$ \\
\hline Ocotea indecora (Schott) Mez & Lauraceae & 16.39 & $\mathrm{X}$ & $\mathrm{X}$ \\
\hline Ocotea minarum (Nees et Mart.) Mez & Lauraceae & 17.14 & $\mathrm{X}$ & $\mathrm{X}$ \\
\hline Ocotea odorifera (Vell.) Rohwer & Lauraceae & 16.62 & $\mathrm{X}$ & $\mathrm{X}$ \\
\hline Ocotea puberula (Rich.) Nees & Lauraceae & 15.73 & $\mathrm{X}$ & $\mathrm{X}$ \\
\hline Ocotea pulchella (Nees et Mart.) Mez & Lauraceae & 15.73 & $\mathrm{X}$ & $\mathrm{X}$ \\
\hline Ormosia fastigiata Tul. $\bigcirc$ & Fabaceae & 65.50 & $\mathrm{X}$ & $\mathrm{X}$ \\
\hline Ouratea floribunda (A.St.-Hil.) Engl. ○ & Ochnaceae & 98.81 & $\mathrm{X}$ & $\mathrm{X}$ \\
\hline Pera glabrata (Schott) Poepp. ex Baill. & Peraceae & 82.83 & $\mathrm{X}$ & $\mathrm{X}$ \\
\hline Persea major (Meisn.) L.E.Kopp $\bigcirc$ & Lauraceae & 23.05 & $\mathrm{X}$ & $\mathrm{X}$ \\
\hline Persea willdenovii Kosterm. & Lauraceae & 23.05 & $\mathrm{X}$ & $\mathrm{X}$ \\
\hline Pimenta pseudocaryophyllus (Gomes) Landrum & Myrtaceae & 30.93 & $\mathrm{X}$ & $\mathrm{X}$ \\
\hline Piptocarpha axillaris (Less.) Baker $\bigcirc$ & Asteraceae & 27.36 & $\mathrm{X}$ & $\mathrm{X}$ \\
\hline Piptocarpha macropoda (DC.) Baker $\bigcirc$ & Asteraceae & 27.36 & $\mathrm{X}$ & $\mathrm{X}$ \\
\hline Protium heptaphyllum (Aubl.) Marchand & Burseraceae & 34.79 & $\mathrm{X}$ & $\mathrm{X}$ \\
\hline Protium spruceanum (Benth.) Engl. & Burseraceae & 34.79 & $\mathrm{X}$ & $\mathrm{X}$ \\
\hline Protium widgrenii Engl. $\bigcirc$ & Burseraceae & 34.79 & $\mathrm{X}$ & $\mathrm{X}$ \\
\hline
\end{tabular}


Table 2 Continued

\begin{tabular}{|c|c|c|c|c|}
\hline Prunus myrtifolia (L.) Urb. & Rosaceae & 106.00 & $\mathrm{X}$ & $\mathrm{X}$ \\
\hline Psidium rufum Mart. ex DC. & Myrtaceae & 33.65 & $\mathrm{X}$ & $\mathrm{X}$ \\
\hline Psychotria nuda (Cham. et Schltdl.) Wawra & Rubiaceae & 30.47 & $\mathrm{X}$ & $\mathrm{X}$ \\
\hline Psychotria vellosiana Benth. & Rubiaceae & 30.47 & $\mathrm{X}$ & $\mathrm{X}$ \\
\hline Qualea cryptantha (Spreng.) Warm. & Vochysiaceae & 47.32 & $\mathrm{X}$ & $\mathrm{X}$ \\
\hline Annona sylvatica A.St.-Hil. & Annonaceae & 46.98 & $\mathrm{X}$ & $\mathrm{X}$ \\
\hline Roupala rhombifolia Mart. ex Meisn. & Proteaceae & 44.46 & $\mathrm{x}$ & $\mathrm{X}$ \\
\hline Rudgea jasminoides (Cham.) Müll.Arg. & Rubiaceae & 31.10 & $\mathrm{X}$ & $\mathrm{X}$ \\
\hline Rudgea triflora Benth. & Rubiaceae & 31.10 & $\mathrm{X}$ & $\mathrm{X}$ \\
\hline Sapium glandulosum (L.) Morong $\bigcirc$ & Euphorbiaceae & 48.02 & $\mathrm{X}$ & $\mathrm{X}$ \\
\hline Sapium haematospermum Müll.Arg. $\bigcirc$ & Euphorbiaceae & 48.02 & $\mathrm{X}$ & $\mathrm{X}$ \\
\hline Schefflera calva (Cham.) Frodin et Fiaschi & Araliaceae & 57.42 & $\mathrm{x}$ & $\mathrm{X}$ \\
\hline Senna velutina (Vogel) H.S.Irwin et Barneby & Fabaceae & 68.13 & $\mathrm{X}$ & $\mathrm{X}$ \\
\hline Siphoneugena densiflora O.Berg & Myrtaceae & NA & $\mathrm{X}$ & $\mathrm{X}$ \\
\hline Siphoneugena reitzii D.Legrand $\bigcirc$ & Myrtaceae & NA & $\mathrm{X}$ & $\mathrm{X}$ \\
\hline Siphoneugena crassifolia (DC.) Proença et Sobral & Myrtaceae & NA & $\mathrm{X}$ & $\mathrm{X}$ \\
\hline Sloanea hirsuta (Schott) Planch. ex Benth. & Elaeocarpaceae & 100.40 & $\mathrm{X}$ & $\mathrm{X}$ \\
\hline Solanum bullatum Vell. & Solanaceae & 31.03 & $\mathrm{X}$ & $\mathrm{X}$ \\
\hline Solanum caavurana Vell. & Solanaceae & 31.03 & $\mathrm{X}$ & $\mathrm{X}$ \\
\hline Solanum leucodendron Sendtn. $\bigcirc$ & Solanaceae & 31.03 & $\mathrm{X}$ & $\mathrm{X}$ \\
\hline Solanum pseudoquina A.St.-Hil. & Solanaceae & 31.03 & $\mathrm{X}$ & $\mathrm{X}$ \\
\hline Sorocea bonplandii (Baill.) W.C.Burger et al. & Moraceae & 77.84 & $\mathrm{X}$ & $\mathrm{X}$ \\
\hline Symplocos celastrinea Mart. & Symplocaceae & 42.90 & $\mathrm{X}$ & $\mathrm{X}$ \\
\hline Symplocos insignis Brand & Symplocaceae & 51.55 & $\mathrm{X}$ & $\mathrm{X}$ \\
\hline Symplocos pubescens Klotzsch ex Benth. & Symplocaceae & 42.90 & $\mathrm{X}$ & $\mathrm{X}$ \\
\hline Tachigali rugosa (Mart. ex Benth.) Zarucchi et Pipoly $\bigcirc$ & Fabaceae & 65.65 & $\mathrm{X}$ & $\mathrm{X}$ \\
\hline Tapirira guianensis Aubl. & Anacardiaceae & 63.98 & $\mathrm{X}$ & $\mathrm{X}$ \\
\hline Ternstroemia brasiliensis Cambess. & Pentaphylacaceae & 103.40 & $\mathrm{X}$ & $\mathrm{X}$ \\
\hline Toulicia subsquamulata Radlk. & Sapindaceae & NA & $\mathrm{X}$ & $\mathrm{X}$ \\
\hline Trichilia casaretti C.DC. & Meliaceae & 49.47 & $\mathrm{X}$ & $\mathrm{X}$ \\
\hline Trichilia catigua A.Juss. & Meliaceae & 49.47 & $\mathrm{X}$ & $\mathrm{X}$ \\
\hline Vantanea compacta (Schnizl.) Cuatrec. & Humiriaceae & 106.60 & $\mathrm{X}$ & $\mathrm{X}$ \\
\hline Vernonanthura discolor (Spreng.) H.Rob. ○ & Asteraceae & 27.21 & $\mathrm{x}$ & $\mathrm{X}$ \\
\hline Vernonanthura divaricata (Spreng.) H.Rob. $\bigcirc$ & Asteraceae & 27.21 & $\mathrm{X}$ & $\mathrm{X}$ \\
\hline Vismia guianensis (Aubl.) Choisy & Hypericaceae & 60.22 & $\mathrm{x}$ & $\mathrm{X}$ \\
\hline Vismia magnoliifolia Cham. et Schltdl. & Hypericaceae & 60.22 & $\mathrm{X}$ & $\mathrm{X}$ \\
\hline Vitex megapotamica (Spreng.) Moldenke & Lamiaceae & 57.86 & $\mathrm{X}$ & $\mathrm{X}$ \\
\hline Vochysia magnifica Warm. $\bigcirc$ & Vochysiaceae & 34.91 & $\mathrm{X}$ & $\mathrm{X}$ \\
\hline Vochysia riedeliana Stafleu & Vochysiaceae & 34.91 & $\mathrm{X}$ & $\mathrm{X}$ \\
\hline Vochysia tucanorum Mart. & Vochysiaceae & 34.91 & $\mathrm{X}$ & $\mathrm{X}$ \\
\hline Zanthoxylum fagara (L.) Sarg. & Rutaceae & 74.24 & $\mathrm{X}$ & \\
\hline
\end{tabular}


distinctiveness of the studied community became more related to the taxonomic groups recorded in the second inventory. Phylogenetic diversity metrics, wood density CWM and AGWB did not show significant relationships with any of the explanatory variables (table 3 ).

Shifts in wood density CWM were negatively related to shifts in standardized phylogenetic diversity (sesMPD), while both sprouting CWM variables shifted as a function of community composition. Changes in CWM of sprouting intensity were also negatively and significantly related to shifts in standardized phylogenetic diversity and mortality rate. Changes in maximum diameter CWM were positively and significantly related to soil
(PC2) and recruitment rate, whereas changes in evolutionary distinctiveness CWM were positively explained by mortality rate. Productivity was positively explained by AGWB of survivors and negatively explained by AGWB of dead individuals, with the latter displaying more important effects than those produced by survivors' AGWB (figure S2-S5; table S1).

\section{DISCUSSION}

The ability to monitor changes in biodiversity is critical to species conservation and ecosystem management. While emerging technologies increase the breadth and scope of

Table 3. Results of the analysis of functional composition temporal variations in relation to the evaluated drivers. The first two columns correspond to the analysis of the existing differences between the inventory years through LMM, with the first one (Between years) giving information on the existence of significant differences through the p-value, and the second presenting the tendency of the variables that varied significantly by the "estimate" value provided by LMM. The third corresponds to an analysis of the variation in the functional composition values $(\triangle \mathrm{CWM})$ by LMM, with the first presenting the significant explanatory factors and the second (fourth) presenting the estimate values provided by the analysis. * Significant $P$.

Resultados del análisis de las variaciones temporales de la composición funcional en relación con los controladores evaluados. Las primeras dos columnas corresponden al análisis de las diferencias existentes entre los años de inventario a través del GLMM, la primera (entre años) brinda información sobre la existencia de diferencias significativas a través del valor $\mathrm{p}$, y la segunda presenta la tendencia de las variables que variaron significativamente por el valor "estimado" proporcionado por el GLMM. El tercero y el cuarto corresponden a un análisis de la variación en los valores de composición funcional $(\triangle \mathrm{CWM})$ por GLM, el primero presenta los factores explicativos significativos y el segundo (cuarto) presenta los valores estimados proporcionados por el análisis.

\begin{tabular}{|c|c|c|}
\hline Response & Main driver (s) & Estimate \\
\hline DCA axis 1 & Year 2 & $-0.05^{*}$ \\
\hline CWM WD & none & \\
\hline CWM Spr Freq & Year 2, DCA axis 1 & $-0.52 * * ;-1.3 * * *$ \\
\hline CWM Sprouting & Year 2, DCA axis 1 & $-0.81 * * ;-1.9 * * *$ \\
\hline CWM Max DBH & PC2, PC2:Year 2 & $-23 * * * ; 13.5^{* *}$ \\
\hline CWM ED & Year 2:DCA axis 1 & $1.65^{*}$ \\
\hline sesPD & none & \\
\hline sesMPD & none & \\
\hline sesMNTD & none & \\
\hline AGWB & none & \\
\hline$\triangle \mathrm{CWM} W \mathrm{WD}$ & $\triangle$ sesMPD & $-0.86^{* *}$ \\
\hline$\Delta$ CWM Spr Freq & $\triangle \mathrm{DCA}$ axis 1 (squared) & $-9.03 *$ \\
\hline$\Delta \mathrm{CWM}$ Sprouting & $\Delta$ DCA axis 1 (squared), $\Delta$ sesMPD, mortality rate & $-8^{*} ;-7^{*} ;-8.3^{*}$ \\
\hline$\Delta \mathrm{CWM}$ Max DBH & $\mathrm{PC} 2$, recruitment rate & $3.5^{* *} ; 3.7^{* *}$ \\
\hline$\triangle \mathrm{CWM}$ ED & mortality rate & $4.25 * *$ \\
\hline$\triangle \mathrm{AGWB}$ & $\Delta$ AGWB mortality, $\triangle$ AGWB survivals & $-1.5^{* * *} ; 0.6^{* * *}$ \\
\hline
\end{tabular}

Note: CWM: Community Weighted Means, $\Delta$ : temporal variation, WD: Wood Density $\left(\mathrm{g} / \mathrm{cm}^{3}\right)$, Spr Freq: Sprouting Frequency (\%), Spr Int: Sprouting Intensity, Max DBH: Maximum Diameter at the Breast Height (cm), ED: Evolutionary Distinctiveness, sesPD: Standardized effect size of Phylogenetic diversity, sesMPD: Standardized effect size of mean pairwise distance, sesMNTD: Standardized effect size of mean nearest neighbor distance, $\Delta$ : delta - difference from first to second year.

Nota: CWM: Medios ponderados de la comunidad; $\Delta$ : variación temporal; WD: Densidad de madera $\left(\mathrm{g} \mathrm{cm}^{-3}\right)$; Frecuencia Spr: Frecuencia de brotación (\%); Spr Int: Intensidad de brote; DBH máx .: diámetro máximo a la altura del seno (cm); ED: distinción evolutiva; sesPD: tamaño del efecto estandarizado de la diversidad filogenética; sesMPD: tamaño del efecto estandarizado de la distancia media por pares; sesMNTD: tamaño del efecto estandarizado de la distancia media más cercana al vecino; $\Delta$ : delta - diferencia de primer a segundo año. 
data acquisition, monitoring efforts are still spatially and temporally fragmented, and taxonomically biased. Small changes or a decline in species abundances can lead to a disruption of a community structure and function (Del Vechio et al. 2016). These processes should not be underestimated, as the disappearance of a community can not only occur by the direct elimination of vegetation. Rather, gradual changes in the functional characteristics and species composition of a community may lead to the emergence of a new community in terms of the combination of species and community function (Del Vechio et al. 2016).

Some of the strongest and most significant catalysts of ecological processes are climatic variations (Fine 2015). Although we will not discuss whether and to what extent climate variations across the time span covered by our study were from anthropogenic origin, we raise the possibility of the recorded changes in community aspects (figures 2 and 4 ) being catalyzed by rainfall variation.

Concerning the changes in floristic composition (table 2), mortality was recorded for 60 species whereas recruitment was recorded for 39 species. Within these mortality- and recruitment-related groups of species, eight species disappeared from the community while three were included. Accordingly, even if local extinction is balanced by immigration, extinction is not random with regard to identity and functional performance, hence changing composition will have important consequences for ecosystem functioning (Hillebrand et al. 2017).

We also recorded structural changes, which could be verified through the significant relationship between $\mathrm{CWM}$ of maximum diameter and soil texture (PC2), in which the changes in the effect of soil over the vegetation between the inventory years are reaffirmed by variation in $\mathrm{CWM}$ of maximum diameter. Communities in sandy soils had a higher reduction in DBH - less water availability contributing to the death of large individuals. Soil texture is an important driver of community structure, influencing species tolerances to habitat conditions (Maia et al. 2020). The different responses displayed by the plants to the same environmental variables through the studied period indicate that precipitation fluctuations in the timeframe of this study likely affected the relationship between plants and soil resources by decreasing water availability (Maia et al. 2020), demonstrated mainly through the high mortality of large individuals (in terms of DBH).

Still concerning the structural changes, the sample units with highest recruitment rates displayed a decrease in CWM of maximum diameter. A few studies have shown that, when recruitment is high, competition for resources among the individuals coinhabiting the community increases, due to less investment in radial growth (Ali and Yan 2017).

Our results emphasize that environmental variation in small spatial and temporal scales can potentially yield significant community changes. For instance, between the first and second inventory years, we found that the effect of species composition over the CWM of evolutionary distinctiveness increased. Additionally, mortality had a positive effect over the $\triangle \mathrm{CWM}$ of evolutionary distinctiveness in the studied timeframe. This seems that the species in the second inventory (year 2017) are more evolutionarily distinct in the context of the entire community than they were in the first inventory, with more species with high ED in the second inventory (Morelli et al. 2018). Therefore, the community is in fact becoming more evolutionarily distant in terms of the species that compose it.

Traits that allow the persistence of species in a certain habitat may increase their fitness, enhancing survival capacity and competitive performance (Bond and Midgley 2001). Sprouting ability can be considered one of these fitness-enhancing traits under stressful conditions (e.g. flooding: Araújo et al. 2017). The number of sprouts, frequency of sprouting and number of sprouting species all decreased in our study area over time. We thus raise the possibility of precipitation oscillations having caused the death of stems, beyond the death of individuals. Furthermore, we found a negative relationship between sprouting variable and net relatedness (sesMPD), showing that the environment is selecting species with low sprouting ability. This is contradictory with other studies which have suggested that disturbance-adapted species should thrive under environmental oscillations (Solar et al. 2015).

An important result to be considered is that the AGWB variation in mortality ( $\triangle$ AGWB mortality) was higher than the variation in survivors ( $\triangle \mathrm{AGWB}$ survivals). This shows that the forest community studied here is losing biomass, which can be partly attributed to the mortality of large trees. For instance, Tachigali rugosa had the highest biomass loss and did not recruit any individuals in the second inventory year. Other studies have found links between the mortality of large trees and extreme drought events in the Amazon region, being mainly attributed to the mechanisms of hydraulic failure from embolism (see Phillips et al. 2009).

In addition, other causes that may have contributed to the biomass decrease recorded here were changes in wood density. There was an increase in the number of species with low wood density in the sample units where sesMPD values also decreased. The increase in the number of lower wood density species recorded by us suggests that the opening of gaps by the death of large-stemmed individuals likely favored the colonization of fast-growth species (Plas et al. 2016). This could mean that: (i) the beginning of the community homogenization process has been recorded, derived from both the increase in the number of colonizing species and the simultaneous death of large trees, moreover (ii) high density wood species are more drought tolerant, therefore, given the predictions of the future scenario in which long periods of drought may occur (Gloor et al. 2015), species with low wood density will be the first to be eliminated. 


\section{CONCLUSIONS}

The search for protection and monitoring of biodiversity is a worldwide concern (including goals to be achieved this year) and studies like ours, about the short term changes of a forest community, not only contribute to a better current understanding of the functioning of forests, but also better capture the possible transformations that the forest community is going through. We verified this through the quantitative changes in the measured parameters (e.g. density wood, biomass), qualitative with regard to the taxonomic composition, consequently generating a change in the phylogenetic and functional structure of the community. We were also able to detect a substitution of species with lower wood density, a species disappearance (we highlight the species Tachigali rugosa, large-stemmed ones and canopy species). All these changes are seen as indications that the community is taking on a new form, which may cause changes in its functioning. What we want to highlight here is that a monitoring study in a short period may indicate the direction in which the community is moving.

\section{ACKNOWLEDGEMENTS}

The authors would like to thank CAPES (Coordenação de Aperfeiçoamento de Pessoal de Nivel Superior), FAPEMIG (Fundação de Amparo à Pesquisa do Estado de Minas Gerais) and CNPQ (Conselho Nacional de Desenvolvimento Científico e Tecnológico) for granting scholarships for authors and funding research. And the RPPN Altomontana for allowing access to data collection and sheltering the team during the collection period.

\section{REFERENCES}

Ali A, ER Yan. 2017. Functional identity of overstorey tree height and understory conservative traits drive aboveground biomass in a subtropical forest. Ecological Indicators 83: 158168. DOI: $10.1016 /$ j.ecolind.2017.07.054

Araújo FC, CN Mendes, GG Pires, GCO Menino, MA Fontes, RM Santos. 2017. Adaptive strategy of tree communities on an environmental harshness hinterland inselberg in Minas Gerais, Brazil. Australian Journal of Botany 65: 463-470. DOI: 10.1071/BT16252

Barton K. 2011. MuMIn: Multi-Model Inference. R Package Version 1.42.1. Available in http://cran.r-project.org/ package $=$ MuMIn

Becker G, D Rodriguez, KR Zamudio. 2013. The Brazilian Adirondacks? Science 340: 428. DOI: 10.1126/ science.340.6131.428-a

Bjørnstad ON. 2018. ncf: Spatial Covariance Functions. R package version 1.2-6. Available in https://cran.r-project.org/ package $=$ ncf

Bond WJ, J Midgley. 2001. Ecology of sprouting in woody plants: the persistence niche. Trends in Ecology \& Evolution 16: 45-51. DOI: 10.1016/S0169-5347(00)02033-4

Chapin III FSI, ES Zavaleta, VT Eviner, RL Naylor, PM Vitousek, HL Reynolds, DU Hooper, S Lavorel, OE Sala, SE Hobbie,
MC Mack, V Díaz. 2000. Consequences of changing biodiversity. Nature 45: 234-242. DOI: 10.1038/35012241

Chave J, D Coomes, S Jansen, SL Lewis, NG Swenson, AE Zanne. 2009. Towards a worldwide wood economics spectrum. Ecology Letters 12: 351-366. DOI: 10.1111/j.14610248.2009.01285.x

Del Vecchio S, A Slaviero, E Fantinato, G Buffa. 2016. The use of plant community attributes to detect habitat quality in coastal environments. AoB PLANTS 8: plw040. DOI: https://doi.org/10.1093/aobpla/plw040

Edwards DP, RM Massam, T Haugaasen, J Gilroy. 2017. Tropical secondary forest regeneration conserves high levels of avian phylogenetic diversity. Biological Conservation 209: 432-439. DOI: $\underline{10.1016 / \mathrm{j} . \text { biocon.2017.03.006 }}$

Esquivel-Muelbert A, D Galbraith, KG Dexter, TR Baker, SLLewis, P Meir, L Rowland, ACL Costa, D Nepstad, O Phillips. 2017. Biogeographic distributions of neotropical trees reflect their directly measured drought tolerances. Scientific Reports 7: 8334. DOI: 10.1038/s41598-01708105-8

Fine PVA. 2015. Ecological and Evolutionary Drivers of Geographic Variation in Species Diversity. The Annual Review of Ecology, Evolution, and Systematics 46: 369-392. DOI: 10.1146/annurev-ecolsys-112414-054102

Gloor M, J Barichivich, G Ziv, R Brienen, J Schöngart, P Peylin, BBarcanteLadvocat Cintra, T Feldpausch, O Phillips, J Baker. 2015. Recent Amazon climate as background for possible ongoing and future changes of Amazon humid forests. Global Biogeochemical Cycles 29: 1384-1399. DOI: $\underline{10.1002 / 2014 \mathrm{~GB} 005080}$

Hillebrand H, B Blasius, ET Borer, JM Chase, JA Downing, BK Eriksson, CT Filstrup, WS Harpole, D Hodapp, S Larsen, AM Lewandowska, EW Seabloom, DB Van de Waal, AB Ryabov. 2018. Biodiversity change is uncoupled from species richness trends: for conservation and monitoring. Journal of Applied Ecology 55: 169-184. DOI: 10.1111/1365$\underline{2664.12959}$

Humphreys AM, R Govaerts, SZ Ficinsk, EN Lughadha, MS Vorontsova. 2019. Global dataset shows geography and life form predict modern plant extinction and rediscovery. Nature Ecology \& Evolution 3: 1043-1047. DOI: 10.1038/ s41559-019-0906-2

Morelli F, AP MØLLER. 2018. Pattern of evolutionarily distinct species among four classes of animals and their conservation status: a comparison using evolutionary distinctiveness scores. Biodiversity and Conservation 27: 381-394. DOI: 10.1007/s10531-017-1441-6

Navarro LM, N Fernández, C Guerra, R Guralnick, WD Kissling, MC Londono, F Muller-Karger, E Turak, P Balnavera, M Costello, A Delavaud, G Serafy, S Ferrier, I Geijzendorffer, GN Geller, W Jetz, E-S Kim, H Kim, C Martin, M McGeoch, TH Mwampamba, JL Nel, E Nicholson, N Pettorelli, M Schaepman, A Skidmore, IS Pinto, S Vergara, P Vihervaara, H Xu, T Yahara, M Gill, H Pereira. 2017. Monitoring biodiversity change through effective global Coordination. Current Opinion in Environmental Sustainability 29: 158-169. DOI: 10.1016/j.cosust.2018.02.005.

Oksanen JF, Blanchet G, Friendly M, Kindt R, Legendre P, McGlinn D, Minchin PR, O'Hara RB, Simpson GL, Solymos P, Stevens MHH, Szoecs E, Wagner H. 2017. vegan: Community Ecology Package. R package version 2.4-0. 
Available in https://CRAN.R-project.org/package=vegan

Oliveira-Filho AT. 2009. Classificação das fitofisionomias da América do Sul cisandina tropical e subtropical: proposta de um novo sistema - prático e flexível - ou uma injeção a mais de caos? Rodriguésia 60: 237-258. DOI: 10.1590/2175-7860200960201

Plas F, P Manning, S Soliveres, E Allan, M Scherer-Lorenzen, $\mathrm{K}$ Verheyen, C Wirth, MA Zavala, E Ampoorter, L Baeten, L Barbaro, J Bauhus, R Benavides, A Benneter, D Bonal, O Bouriaud, H Bruelheide, F Bussotti, M Carnol, B Castagneyrol, Y Charbonnier, Y David, A Coomes, A Coppi, CC Bastias, SM Dawud, H Wandeler, T Domisch, L Finér, A Gessler, A Granier, C Grossiord, V Guyot, S Hättenschwiler, H Jactel, B Jaroszewicz, FX Joly, T Jucker, J Koricheva, H Milligan, S Mueller, B Muys, D Nguyen, M Pollastrini, S Ratcliffe, K Raulund-Rasmussen, F Selvi, J Stenlid, F Valladares, L Vesterdal, D Zielínski, M Fischer. 2016. Biotic homogenization can decrease landscape-scale forest multifunctionality. PNAS 13: 3557-3562. DOI: 10.1073 /pnas. 1517903113

Phillips OL, L Aragão, SL Lewis, JB Fisher, J Lloyd, G LópezGonzález, Y Malhi, A Monteagudo, J Peacock, CA Quesada, G van der Heijden, S Almeida, I Amaral, L Arroyo, G Aymard, TR Baker, O Bánki, L Blanc, D Bonal, P Brando, J Chave, ACA Oliveira, ND Cardozo, CI Czimczik, TR Feldpausch, MA Freitas, E Gloor, N Higuchi, E Jiménez, G Lloyd, P Meir, C Mendoza, A Morel, DA Neill, D Nepstad, S Patiño, MC Peñuela, A Prieto, F Ramírez, M Schwarz, J Silva, M Silveira, AS Thomas, H terSteege, J Stropp, R Vásquez, P Zelazowski, EA Dávila, S Andelman, A Andrade, KJ Chao, T Erwin, A Di Fiore, EC Honorio, H Keeling, TJ Killeen, WF Laurance, AP Cruz, NCA Pitman, PN Vargas, H Ramírez-Angulo, A Rudas, R Salamão, N Silva, J Terborgh, A Torres-Lezama. 2009. Drought sensitivity of the Amazon rainforest. Science 323: 1344-1347. DOI: 10.1126/science. 1164033

Poorter L, MT Van Der Sande, J Thompson, EJMM Arets, A Alarcón, J Álvarez-Sánchez, N Ascarrunz, P Balvanera, B Barajas-Guzmán, A Boit, F Bongers, FA Carvalho, F Casanoves, Cornejo-G Tenorio, FRC Costa, CV de Castilho, JF Duivenvoorden, LP Dutrieux, BJ Enquist, F Fernández-Méndez, B Finegan, LHL Gormley, JR Healey, MR Hoosbeek, G Ibarra-Manríquez, AB Junqueira, C Levis, JC Licona, LS Lisboa, WE Magnusson, M Martínez-Ramos, A MartínezYrizar, LG Martorano, LC Maskell, L Mazzei, JA Meave, F Mora, R Muñoz, C Nytch, MP Pansonato, TW Parr, H Paz, EA Pérez-García, LY Rentería, J Rodríguez-Velazquez,
DMA Rozendaal, AR Ruschel, B Sakschewski,B SalgadoNegret, J Schietti, M Simões, FL Sinclair, PF Souza, FC Souza, J Stropp, H terSteege, NG Swenson, K Thonicke, M Toledo, M Uriarte, P van der Hout, P Walker, N Zamora, M Peña-Claros. 2015. Diversity enhances carbon storage in tropical forests. Global Ecology Biogeography 24: 13141328. DOI: $10.1111 /$ geb. 12364

Poorter L, Van Der Sande MT, Arets EJMM, Scarrunz NA, Enquist BJ, Finegan B, Licona JC, Martínez-Ramos M, Mazzei L, Meave JA, Muñoz R, Nytch CJ, Oliveira AA, Pérez-García EA, Prado-Junior P, Rodríguez-Velázques J, Ruschel AR, Salgado-Negret B, Schiavini I, Swenson NG, Tenorio EA, Thompson J, Toledo M, Uriarte M, van der Hout P, Zimmerman JK, Peña-Claros M. 2017. Biodiversity and climate determine the functioning of Neotropical forests. Global Ecology and Biogeography 26: 1423-1434. DOI: $10.1111 /$ geb.12668

Pulla S, J Riotte, HS Suresh, HS Dattaraja, R Sukumar. 2016. Controls of Soil Spatial Variability in a Dry Tropical Forest. PLOS ONE 11(4): e0153212. DOI: 10.1371/journal. pone. 0153212

R Core Team. 2019. R: A language and environment for statistical computing. R Foundation for Statistical Computing, Vienna, Austria. Available in https://www.R-project.org/

Rejou-Mechain M, Tanguy A, Piponiot C, Chave J, Herault B. 2017. BIOMASS: an R package for estimating above-ground biomass and its uncertainty in tropical forests. Methods in Ecology and Evolution 8(9). DOI: 10.1111/2041-210X.12753

Ribeiro MC, JP Metzger, AC Martensen, F Ponzoni, M Hirota. 2009. Brazilian Atlantic forest: how much is left, and how is the remaining forest distributed? Implications for conservation. Biological Conservation 142: 1141-1153. DOI: 10.1016/j.biocon.2009.02.021

Sheil D, DFRP Burslem, D Alder. 1995. The Interpretation and misinterpretation of mortality rate measures. Journal of Ecology 83: 331-333. DOI: 10.2307/2261571

Solar RRC, J Barlow, J Ferreira, E Berenguer, AC Lees, JR Thomson, J Louzada, M Maués, NG Moura, VHF Oliveira, JCM Chaul, JH Schoereder, IGC Vieira, RM Nally, TA Gardner. 2015. How pervasive is biotic homogenization in human-modified tropical forest landscapes? Ecology Letter 18: 1108-1118. DOI: 10.1111/ele.12494

Tsirogiannis C, B Sandel. 2016. PhyloMeasures: a package for computing phylogenetic biodiversity measures and their statistical moments. Ecography 39: 709-714. DOI: 10.1111/ ecog. 01814 . 


\section{SUPPLEMENTARY MATERIAL}

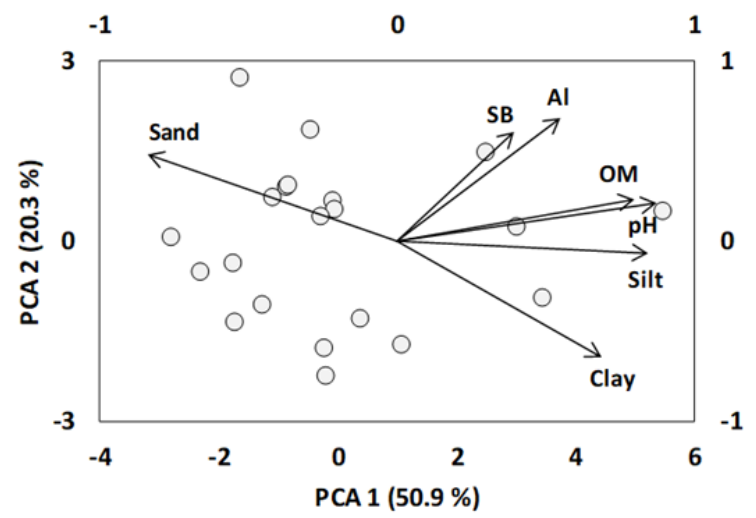

Figure S1. Principal Components Analysis (PCA) for edaphic variables of fertility and texture for the sample units of the Uppermontane Semideciduous Tropical Forest sampled. Note: Al: Aluminum; SB: Sum of Bases; OM: Organic Matter; $\mathrm{pH}$ : $\mathrm{pH}$ in water; Silt: proportion of Silt; Sand: proportion of Sand; Clay: proportion of Clay.

Análisis de Componentes Principales (PCA) para variables edáficas de fertilidad y textura para las unidades de muestra del Bosque Tropical Semideciduo Uppermontane muestreado. Nota: Al: aluminio; SB: Suma de bases; OM: materia orgánica; $\mathrm{pH}$ : $\mathrm{pH}$ en agua; Limo: proporción de Limo; Arena: proporción de arena; Arcilla: proporción de arcilla.

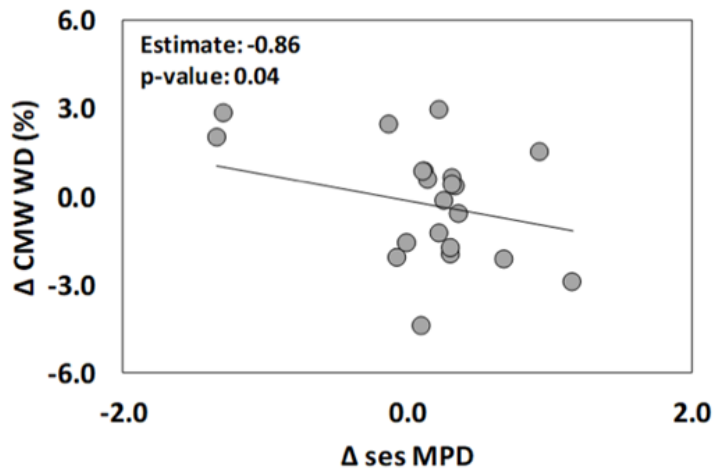

Figure S2. Relation between the Temporal Variation $(\Delta)$ of the Wood Density Community Weighted Means (\%) and the Standardized effect size of mean pairwise distance (sesMPD) for the sample units of the Upper montane Semi-deciduous Tropical Forest.

Relación entre la variación temporal $(\Delta)$ de las medias ponderadas por la comunidad de densidad de madera (\%) y el tamaño del efecto estandarizado de la distancia media por pares (sesMPD) para las unidades de muestra del bosque tropical semi-caducifolio montano superior.

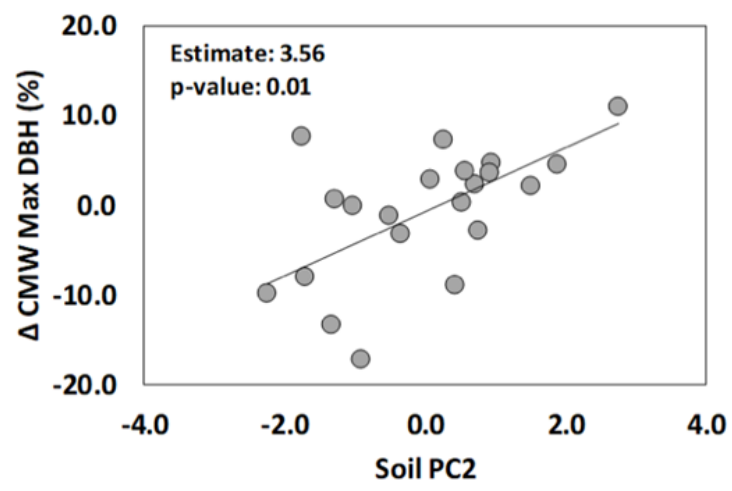

Figure S3. Relation between the Temporal Variation $(\Delta)$ of the Maximum Diameter at the Breast Height Community Weighted Means (\%) and the Second axis of the Soil Principal Component Analysis (Soil PC2) for the sample units of the Upper montane Semi-deciduous Tropical Forest.

Relación entre la variación temporal $(\Delta)$ del diámetro máximo en la media ponderada de la comunidad de la altura del seno (\%) y el segundo eje del análisis de componentes principales del suelo (PC2 del suelo) para las unidades de muestra del semi-caducifolio montano superior Bosque tropical.

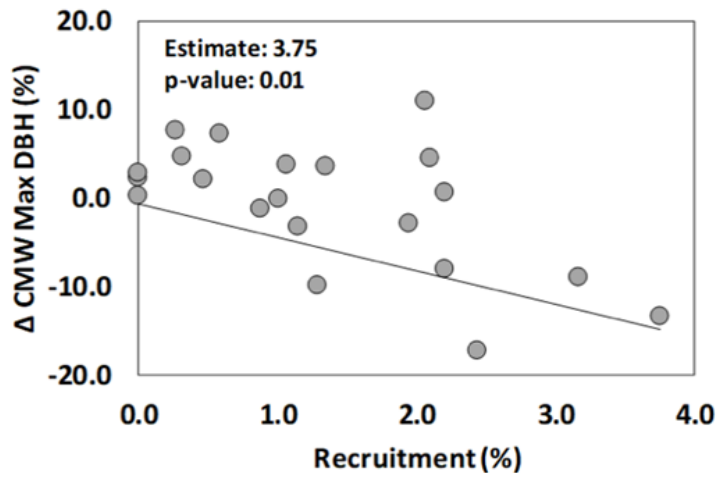

Figure S4. Relation between the Temporal Variation $(\Delta)$ of the Maximum Diameter at the Breast Height Community Weighted Means (\%) and the Recruitment Rate for the sample units of the Upper montane Semi-deciduous Tropical Forest.

Relación entre la variación temporal $(\Delta)$ del diámetro máximo en la media ponderada comunitaria de la altura del seno (\%) y la tasa de reclutamiento para las unidades de muestra del bosque tropical semi-deciduo montano superior. 


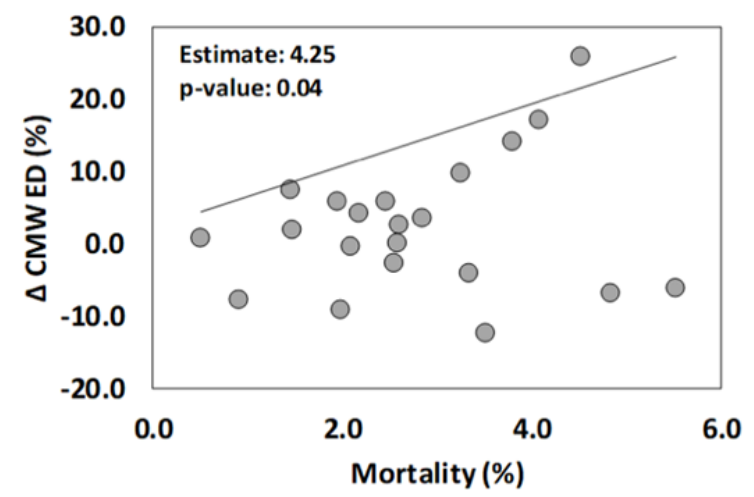

Figure S5. Relation between the Temporal Variation $(\Delta)$ of the Evolutionary Distinctiveness Community Weighted Means (\%) and the Mortality Rate for the sample units of the Upper montane Semi-deciduous Tropical Forest.

Relación entre la variación temporal $(\Delta)$ de las medias ponderadas por la comunidad de distinción evolutiva (\%) y la tasa de mortalidad para las unidades de muestra del bosque tropical semicaducifolio montano superior.

Table S1. Balance of $\triangle \mathrm{AGB}$ for the two inventories of the seven species with the highest VI.

Balance de $\triangle \mathrm{AGB}$ para los dos inventarios de las siete especies con el VI más alto.

\begin{tabular}{|c|c|c|c|c|c|}
\hline \multicolumn{3}{|c|}{ Year 1} & \multicolumn{3}{|c|}{ Year 2} \\
\hline Species & AGB & $\triangle \mathrm{AGBmort}$ & Species & AGB & $\Delta \mathrm{AGBmort}$ \\
\hline Rudgeajasminoides & 13.14458 & 0.3137912 & Rudgeajasminoides & 11.22698 & 0.002443 \\
\hline Tachigali rugosa & 46.84067 & 1.8886353 & Alchorneatriplinervia & 23.07527 & 0.005138 \\
\hline Alchorneatriplinervia & 21.69688 & 0.372533 & Tachigali rugosa & 39.1154 & 0 \\
\hline Solanum leucodendron & 4.15601 & 0.4826296 & Rudgeatriflora & 2.107696 & 0.000583 \\
\hline Rudgeatriflora & 1.918495 & 0.0056534 & Amaioua intermedia & 5.053149 & 0.002291 \\
\hline Guatteriavillosissima & 6.484367 & 0.1229875 & Solanum leucodendron & 0.956283 & 0 \\
\hline Siphoneugenadensiflora & 5.659164 & 0.0255838 & Siphoneugenadensiflora & 6.194287 & 0.001721 \\
\hline
\end{tabular}

